NEWS FEATURE
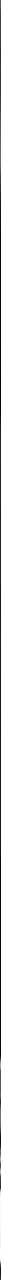

水素自動車の未来

\title{
Fuel of the future?
}

JefF TOLLEFson 2010年4月 29 日号 Vol. 464 (1262-1264)

バイオ燃料や電気自動車に押され、忘れられかけていた水素燃料電池自動車が、

ここにきて再び注目され始めた。

2003 年、ブッシュ前米国大統領は、水 素然料イニシアチブに 12 億ドルの資金 を提供して 2020 年までの水素燃料電池 自動車の市販をめざすと発表し、「今日 生まれた子どもが初めて運転する自動車 は、水素を燃料とする無公害車になるか もしれません」と語つた。

この提案は魅力的だった。水素燃料電 池自動車ができれば、外国の油田と縁 を切ることができるし、排気管からは 水蒸気しか出てこないからだ。議会は
滞りなく予算を承認し、米国エネルギー 省（DOE） やその他の研究機関も動き 始めた。ところがその後、バイオ然料が 脚光を浴び、続いて二次電池自動車（電 気自動車) が注目されるようになると、 こうした取り組みのすべてが忘れられ てしまった。

Steven Chu が 2009 年にDOE 長官 に就任したとき、水素然料電池自動車に 期待する余地は既にないようにみえた。 彼は水素燃料イニシアチブが抱えている
4 つの主要な問題を明らかにした。自動 車メーカーはまだ、頑丈で長持ちする安 価な燃料電池も、長距離走行ができる量 の水素をタンクに貯蔵する方法も開発で きていなかった。新しい水素供給インフ ラも必要だし、それができても、天然ガ ス以外の低炭素エネルギー源を使って水 素を作る費用対効果の高い方法を開発で きないかぎり、地球温暖化ガスを削減す る効果はないに等しい。

就任から 4 か月後の 2009 年 5 月、 
Chu は燃料電池自動車の研究のための DOE の当初予算を削減する方針を打ち 出した。バイオ燃料や二次電池自動車の ほうが「資金を投入するのにはるかによ い分野」であると判断したからだ。Chu の決断の背景には、水素自動車の開発に 多額の資金を投入することに対する多く の人々からの批判があった。環境主義者 の中にさえ、水素燃料イニシアチブに反 対する人々がいた。「実現不可能な技術 を目標に揭げることで、ガソリンに依存 する現状を永続させようとする策略」と 見なしたからだ。

しかし、予算カットの提案は水素自 動車の支持者を発奮させ、数か月後に は、議論が決着していなかったことが明 確になった。バイオ燃料や二次電池自動 車に莫大な投資をしている自動車メー カー自身も、長期的には、水素燃料電池 には無視できない可能性があることを 感じていた。水素自動車の支持者は効果 的なロビー活動を展開し、議会はやがて 投票により Chu の決定を覆し、予算を 復活させた。

2009 年 9 月 9 日、ドイッのシュッッ トガルトで、ダイムラー、フォード、GM (ゼネラルモーターズ)、ホンダ、現代 (ヒュンダイ)、起亜 (キア)、ルノー、日 産、トヨタの主要自動車メーカー 9 社が、 2015 年までに燃料電池自動車を商品化す るという共同声明に署名した。翌日、こ れに連携してベルリンでも発表があった。 シェルやスウェーデンのバッテンフォー ルを含むエネルギー会社のグループが、 ダイムラーとともに、ドイツ国内に燃料 電池自動車のための水素供給インフラの 整備に着手することで合意したのだ。

水素自動車の支持者は自信を深めてい る。ドイツの国立水素燃料電池技術機構 （NOW）を率いる Klaus Bonhoff は、「こ の覚書は、前進への産業界の決意表明で す」という。NOW は、ドイツの水素燃 料電池開発プログラムをリードする機関 として同国政府が 2008 年に創設したも ので、ベルリンを本拠地としている。

Nature は今回、水素燃料電池自動車
が直面する 4 つの主要な問題を検討し、 どちらの言い分にも妥当な点があること を明らかにする。問題の中には近いうち に解決しそうなものもあるが、そう簡単 ではないものもある。

\section{燃料電池}

燃料電池は、少なくとも概念的には、空 気中から取り込んだ酸素と燃料タンクか ら取り込んだ水素を反応させて、水蒸気 と電力を作り出すだけの装置だ。燃料電 池自動車では、その電力を通常の電動機 に供給してタイヤを回すことになる。

しかし実際には、燃料電池は決して単 純な装置ではない。反応を制御しながら 電流を取り出すためには、ノズル、膜、 触媒などを巧妙に組み合わせなければな らないからだ。難しいのはそこである。 これだけの複雑な部品をつめ込んで、軽 量で、安価で、頑丈で、長持ちする装置 を作らなければならないうえに、速やか に加速できるだけでなく、ライトやエア コンやラジオなどへの電力も供給しなけ ればならない。

10 年前には、この目標ははるか遠く にあると思われた。自動車メーカーは、 実験用の燃料電池自動車を低温にさらさ ないように気を付けていた。発電を停止 したときに、残った水蒸気が凍結して、 内部のデリケートな機構を損傷すること を心配したからである。燃料自動車を輸 送するときには、暖房したトレーラーに 積み込んでいたほどだった。

しかし、この 10 年間で燃料電池技術 は大きく進歩した。2009 年 1 月まで GM の燃料電池プログラムのリーダーを 務めていた Byron McCormick は、「あ る朝、誰かに名案が浮かんで大きな問題 が解決できたわけではありません。すべ ては小さな積み重ねでした」という。

例えば、GM の燃料電池自動車は、車 が停止した後に $1 \sim 2$ 分間燃料電池の排 気システムを動かし続け、電池の残留熱 を使ってシステムから水を追い出すこと により、低温下での問題を軽減した。ト ヨ夕によると、実験的に燃料電池を搭載
したクルーガー（日本国外での販売名は ハイランダー）というSUV は、マイナ ス 37 度でエンジンを始動できるという。 高価な触媒の使用量を減らす技術開発 も進んでいる。GM の燃料電池の場合、 現在は約 80 グラム（約 43 万円）の白金 を使用する。しかし薄膜化で使用量は 30 グラム未満となった。10 年以内には 10 グラム未満にできるだろうと予想する。

こうした進歩は燃料電池の価格低下に つながる。大量生産のコスト予測に基づ く DOE の推定によれば、2002～ 2008 年までの間に、燃料電池による 1 キロ ワット当たりの発電コストは 75 パーセ ント近く低下した。トヨ夕の研究開発 拠点であるトヨタテクニカルセンター USA（カリフォルニア州トーランス）の Craig Scott マネジャーは、2010 年代半 ばまでに発売される予定の燃料電池自動 車は「競争力のある価格」になり、「確 実に多くの人々にお届けできるでしょ う」という。

\section{水素燃料タンク}

2009 年 6 月、トヨ夕の技術者と米国政 府のモニターが 2 台の燃料電池クルー ガーに乗ってトーランスの米国トヨ夕本 社を出発し、途中で水素燃料を補給する ことなく、533 キロメートルの公道を 走って戻ってきた。この試験走行データ に基づいて計算すると、水素燃料電池 自動車は、1 個の水素燃料タンクで 693 キロメートルも走行できることになる。 これは、現在のガソリン自動車と比べて も遜色ない数字だ。

水素燃料を補給することなくこんなに 長距離を走行することも、10 年前には 到底不可能と思われていた。水素ガスを そのままタンクに貯蔵するのは簡単だ。 しかし、十分な量の水素ガスを自動車に 搭載しようとすると、途方もなく大きい タンクが必要になり、人や荷物を入れる スペースがなくなってしまう。水素ガス を数百気圧に圧縮して貯蔵する手はある が、安全に貯蔵するには、非常に頑丈な タンクが必要だ。液体水素を使う方法も 
あるが、マイナス253 度の断熱タンクが 必要で、自動車の重量、複雑さ、経費が 増大してしまう。

3つの方法を検討すると、圧縮水素の 形で貯蔵するのが比較的単純であること がわかる。ほとんどの企業は、最新の炭 素繊維を使った高圧タンクを採用してい る。こうしたタンクは最大 680 気圧の 水素を貯蔵できるが、比較的軽量だ。燃 料電池自動車の走行距離をさらに伸ばす ために、多くの企業がガソリンと電気を 併用するハイブリッドカーや電気自動車 と同じ「回生ブレーキ」技術も使ってい る。これは、ブレーキをかけるときにエ ネルギーを取り出して補助バッテリーに 貯蔵し、後で加速するときにそれを再利 用するシステムである。

実際、水素燃料電池自動車と二次電池 自動車は共に電動機を使っているため、 多くの技術を共有している。本当に違つ ているのは、電源が燃料電池か二次電池 かという点だけだ。Scottによると、リ チウムイオン電池を利用する電気自動車 が 1 回の充電で $150 \sim 250$ キロメート ル以上走行できる可能性はないという。 都市部を走行するならこれで十分かもし れないが、消費者は田舎の長距離ドライ
ブにも使える車を期待している。だから、 長期的にみれば、水素自動車の走行距離 の長さは有利に㗢くかもしれない。

\section{水素供給インフラ}

1 回の燃料補給で長距離走行できる自動 車でも、必ず然料は補給しなければなら ない。ここで、「ニワトリが先か、卵が 先か」の問題が生じる。水素然料を供給 する水素ステーションのネットワークが 整備されるまで、燃料電池自動車の売り 上げが大きく伸びることはないだろう。 しかし、水素燃料を必要とする燃料電池 自動車がかなりの台数にならないかぎ り、そうしたネットワークを整備するの に必要な資本を投下しようとする者は現 れないはずだ。

既存のガソリンスタンドに水素ポン プを追加することはできるし、実際、そ のような施設もある。水素ポンプは、外 見上は従来のポンプとさして変わらな い。ただ、圧縮水素ガスを燃料タンクに 入れるには、ガソリンのようにタンクの 補給口にノズルを差し込み、あとは重力 に任せておけばよいというわけにはい かない。ノズルと自動車の間はしつかり 密閉しなければならないし、希望の圧力
に達するまで高压ポンプで水素を送り 込まなければならない。今の水素ポンプ は、普通の消費者が使える程度に簡単に 操作でき、安全なものになっている。し かし、最大圧力まで然料を補給しようと するなら、完璧に動作するものでなけれ ばならない。

自動車メーカーにとつては、水素供給 スタンドのネットワークがどのくらい速 やかに広がるかという問題のほうが重要 だ。例えば、米国では水素ポンプは現時 点で数十か所にしか設置されておらず、 この現状を変える取り組みがなされてい るようにはみえない。つい最近まで、ほ かの国々も同じような状況だった。

水素自動車の支持者が 2009 年にドイ ツで成立した合意を重視し、「ニワトリ と卵」の行き詰まりが打開されると期 待するのは、それゆえなのだ。自動車 メーカーは水素自動車の開発を約束し、 NOW はドイッ全土に数年以内に数百か 所、2010 年代末までに 1000 か所の水 素ポンプのネットワークを整備すること を約束した。これだけあれば、都市部は 広くカバーされ、それ以外の地域でも高 速道路に沿つて定期的に燃料を補給でき るようになる。Bonhoffによると、コン

\section{水素自動車への挑戦}

水素燃料電池自動車の未来は、水素源、水素供給インフラ、車載燃料タンク、

車載燃料電池という4つの主要要素の進歩にかかっている。

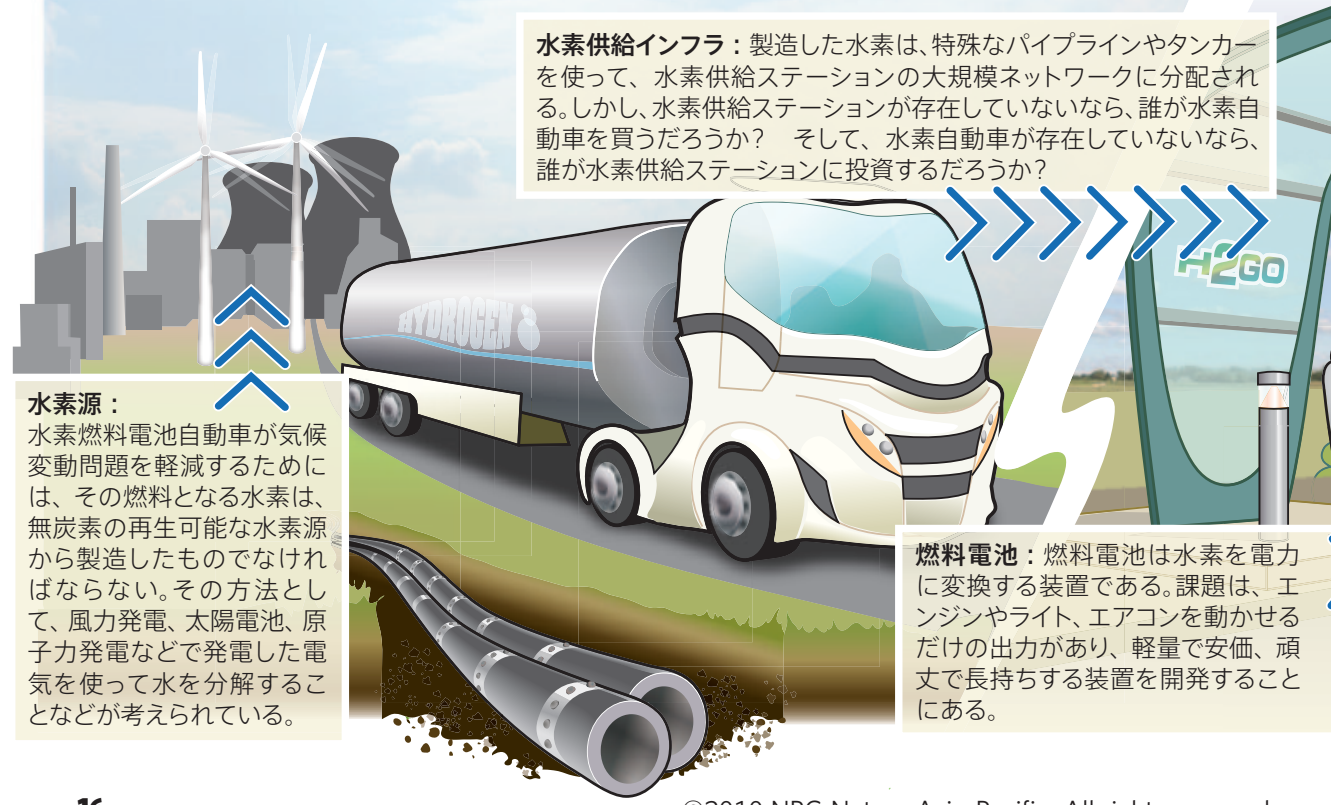

燃料タンク : 燃料電池自動車 のタンクには、次の水素供給ス テーションまでの数百 $\mathrm{km}$ を走 行できるだけの水素を貯蔵で きなければならない。液体水 素の形で貯蔵するにはマイナ ス253 度の断熱タンクが必要 になるため、ほとんどの企業 は、水素ガスを圧縮し、高強度 の炭素繊維を使ったタンクに 貯蔵する方式を採用している。

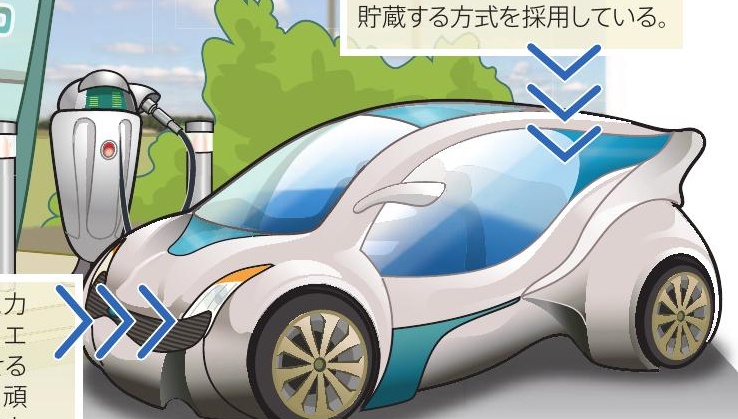

$$
\text { . }
$$

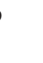


ソーシアムが想定している費用は、エネ ルギー会社が同じ期間にガソリン燃料 ンフラの維持、改良、拡大にかける費用 と同程度であるという。

GM の燃料電池プログラムのリーダー である Charlie Freese は、ドイッより はるかに広い米国などの国々でも、水素 供給インフラの整備コストはそう法外な ものにはならないとみる。水素自動車の 市販が始まる初期段階には、ロサンゼル ス盆地に約 2 億ドル（約 180 億円）の 費用で 50 か所の水素ステーションを設 置できるだろう。さらに、米国全土にネッ トワークを張り巡らせるためには約 1 万 1000 か所の水素ステーションが必要 になるかもしれない。「その費用は、提 案されているアラスカパイプラインプロ ジェクトとだいたい同じくらいです」と Freese はいう。アラスカのノーススロー プから北米の市場まで天然ガスを輸送す るパイプラインの建設は、およそ 350 億ドル（約 3 兆 2000 億円）のプロジェ クトになるといわれている。

\section{水素の製造}

気候変動の観点からいえば、問題は、そ もそもどこから水素ガスを手に入れる のか、という点にある。現時点で最も安 価に水素を製造できるのは、水蒸気と天 然ガスの化学反応を利用する方法であ る。しかし、反応過程で二酸化炭素も 発生するため、この方法で製造した水素 を使って燃料電池自動車を走らせても、 地球温暖化ガスの総排出量は従来のガ ソリン自動車とあまり変わらないこと になってしまう。そのため、燃料電池 自動車が使う水素は、無炭素の再生可 能な水素源から製造したものであるこ とが重要になる。

バッテンフォールはこれを機会ととら え、風力発電による余剩電力を使って水 分子を分解し、20 台の燃料電池バスの 燃料となる水素を製造する施設をハンブ ルクに建設している。風は常に同じょう に吹いているわけではないため、電力会 社は風力タービンを余分に建設して、い

\section{燃料電池の仕組み}

燃料電池はタンクからの水素 $\left(\mathrm{H}_{2}\right)$ と空気か らの酸素 $\left(\mathrm{O}_{2}\right)$ を結合させて水蒸気 $\left(\mathrm{H}_{2} \mathrm{O}\right)$ と電気 $\left(\mathrm{e}^{-}\right)$を作る。

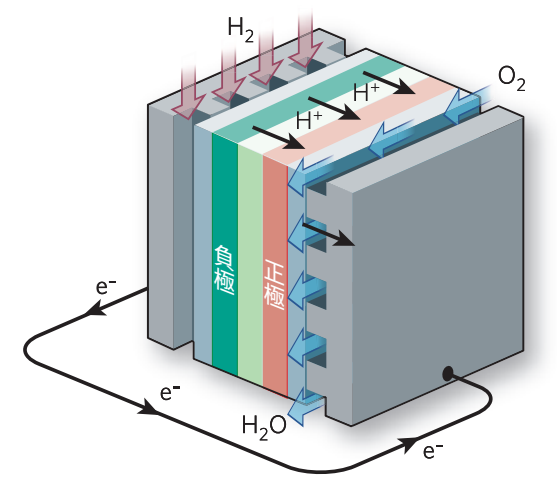

ろいろな場所に分散させていることが多 い。しかし、多くの場所で一斉に風が吹 くと、送電網が扱いきれない量の電気が できてしまう。今のところ、そのような 場合には風力タービンを停止させるしか ない。けれども、バッテンフォールがハ ンブルクに建設している施設が完成すれ ば、余剩電力が生じた場合には電解工 ニットを作動させて水素を製造し、送電 網を安定に保つことができる。

「実際のところ、水素供給インフラを 整備できるかどうかという問題ではな いのです」と Freese はいう。「問題は、 再生可能エネルギーを利用するとき、水 素インフラを整備せずに本当にすませら れるのか、という点なのです」。

\section{どちらをとるか}

こうした議論にすべての人が納得して いるわけではない。自動車メーカーが計 画どおり 2015 年までに燃料電池自動車 を発売することができたとしても、顧客 基盤を確立し、生産量を増やし、コスト を下げるには何年もかかるだろう。ほと んどの自動車メーカーは、2020 年まで、 ひょつとすると 2025 年まで、この種の 自動車で利益を上げられる可能性はな いと予想している。一方で、自動車メー カーとエネルギー会社はバイオ燃料や 二次電池自動車の研究開発も進めてい るが、いずれも独自の燃料（エネルギー）
供給システムを必要とする。これらのイ ンフラを同時に整備することは不可能 かもしれない。

こうした不安は自動車業界も感じてい る。例えばフォードは燃料電池について は長期的な研究しか進めておらず、現時 点では水素自動車の市販は計画していな い。BMW は両賭けをして、ガソリンで も水素でも走行できる内燃機関を備えた 自動車の研究を行うことで負けを防ごう としている。

水素自動車の支持者の一部は、棲み分 けが進むだろうと予想している。すなわ ち、二次電池自動車は都市部の走行、燃 料電池自動車は長距離走行に利用される ようになり、高速道路に沿って多数の水 素ポンプが建設されるだろうというので ある。けれども、マサチューセッツ工科 大学 (米国ケンブリッジ) のスローン自 動車研究所の John Heywood 所長は、 このゲームに参戦している人々の中に、 自分が何をしているかを本当にわかって いる者がいると考えてはならない、と釘 を刺す。

Heywood は、最初に市販される燃料 電池自動車は、完成品というょりはむし ろ、企業がその性能を評価し、消費者の 反応をみるための「量産試作品」になる だろうという。トヨ夕は、1997 年に発 売したハイブリッド自動車「プリウス」 で、このアプローチをとつた。水素自動 車や二次電池自動車がハイブリッド自動 車よりも短期間で完成されると考える理 由はない。Heywood は、いずれにせよ、 世界の自動車を変革するには 30 年以上 かかる可能性があり、今日の自動車メー カーも、そのくらいの時間枠で物事を考 えていると指摘する。

「電気と水素、道は 2 つります。ど ちらかが格段によいことがはっきりする までは、両方に投資することになるで しょう」と彼はいう。「どちらの道を進 むべきか、現時点では不明です」。

(翻訳 : 三枝小夜子)

Jeff Tollefson はワシントン D.C. 在住の Nature 通信員。 